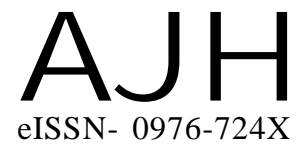

Received : 28.09.2016

Accepted : 29.11.2016
THEASIAN JOURNALOF HORTICULTURE

Volume 11 | Issue 2 | December, 2016 | 411-419

Visit us -www.researchjournal.co.in
DOI : 10.15740/HAS/TAJH/11.2/411-419

A REVIEW

\title{
Effect of fertigation, splitting and mulching on different fruit crops
}

Members of the Research Forum

Associated Authors:

${ }^{1}$ Department of Fruit Science and

PSMA, ASPEE College of

Horticulture and Forestry, Navsari

Agriucltural University, NAVSARI

(GUJARAT) INDIA

${ }^{2}$ ASPEE Agricultural Research and Development Foundation, MALAD (M.S.) INDIA

Author for correspondence :

P.B. JADHAV

ASPEE Agricultural Research and

Development Foundation, MALAD (M.S.) INDIA

\section{P.B. JADHAV, B.V. PADHIAR ${ }^{1}$ AND S.S. DEKHANE ${ }^{2}$}

KEY WORDS : Fertigation, Splitting, Mulching, Fruit crops

HOW TO CITE THIS ARTICLE : Jadhav, P.B., Padhiar, B.V. and Dekhane, S.S. (2016). Effect of fertigation, splitting and mulching on different fruit crops. Asian J. Hort., 11(2) : 411-419, DOI : 10.15740/HAS/TAJH/11.2/411-419. 